\title{
Rola przemysłu w gospodarce układów regionalnych Unii Europejskiej
}

We współcześnie zachodzących przemianach w gospodarce światowej, związanych z przechodzeniem od industrialnej poprzez postindustrialną do informacyjnej fazy rozwoju cywilizacyjnego, istotnym zagadnieniem badawczym są procesy dostosowawcze różnorodnych struktur gospodarczych do zmieniających się uwarunkowań rozwoju gospodarczego, związanych głównie z nasilającymi się procesami globalizacyjnymi i integracyjnymi. Ich efektem jest przebudowa sektorowej struktury gospodarczej, w której działalność przemysłowa, będąca podstawową bazą ekonomiczną w fazie industrialnej, ustępuje działalności usługowej, zwłaszcza związanej z nauką i oświatą. Konsekwencją tego procesu jest zmiana dotychczasowych struktur przestrzennych i branżowych przemysłu oraz jego funkcji w rozwoju gospodarczym układów przestrzennych różnej skali, od układów lokalnych przez regionalne po krajowe i międzynarodowe. Zmieniające się warunki gospodarowania prowadzą do pogłębienia różnic w poziomie rozwoju układów regionalnych Unii Europejskiej. Znaczącą rolę w tym zakresie, co podkreśla wielu autorów (m.in. Domański 1997; Rachwał 2008; Rydz, Szymańska 2006; Stryjakiewicz 1999; Tobolska 2004, 2006; Zioło 2001, 2008), odgrywaja duże przedsiębiorstwa przemysłowe, między którymi w procesie transformacji gospodarczej kształtują się różnego typu nowe powiązania przestrzenno-produkcyjne. Ponadto działalność przemysłowa w większości regionów krajów wysoko rozwiniętych gospodarczo zmniejsza swoją funkcję w zakresie aktywizacji zasobów pracy, co jest konsekwencją postępującej mechanizacji i automatyzacji produkcji. $Z$ tej perspektywy istotne wydają się pytania o rolę, jaką będzie pełnił przemysł w nowej fazie rozwoju cywilizacyjnego i jakie będzie generował efekty mnożnikowe rozwoju gospodarczego (por. Domański, Gwosdz (red.), 2005; Wiedermann 2007, 2008).

Celem artykułu jest przedstawienie zróżnicowania przestrzennego przemian potencjału przemysłowego oraz zmian udziału przemysłu w gospodarce układów regionalnych Unii Europejskiej (w świetle mierników zatrudnienia i wartości dodanej brutto), a także określenie zróżnicowania cech zasobów wysoko kwalifikowanego kapitału ludzkiego w przemyśle jako czynnika przewagi konkurencyjnej układów regionalnych Unii Europejskiej. We współczesnej fazie rozwoju cywilizacyjnego kapitał ten stanowi jeden z najważniejszych elementów konkurencyjności regionalnych i krajowych układów przestrzennych (por. Jasiński 2001, Misala 2001). W celu określenia funkcji przemysłu w budowie gospodarki opartej na wiedzy określono związki między wysokością nakładów inwestycyjnych w przemyśle a potencjałem zatrudnionych w działalnościach badawczo-rozwojowych. W pracy podjęto także próbę oceny przydatności poszczególnych mierników rozwoju prze- 
mysłu do określenia ich roli w gospodarce układów regionalnych w warunkach nasilających się procesów globalizacji i integracji europejskiej fazy informacyjnej rozwoju cywilizacyjnego. Określenie przydatności analizowanych wskaźników może mieć istotne znaczenie aplikacyjne zarówno dla potencjalnych inwestorów oraz kadry zarządzającej przedsiębiorstw przemysłowych planujących rozwijać działalność czy też podejmować działania restrukturyzacyjne w zakresie dostosowania określonych rodzajów produkcji do miejsca jej prowadzenia, jak i dla instytucji zajmujących się planowaniem rozwoju układów krajowych, regionalnych czy lokalnych. Praca jest kontynuacją rozpoczętego wcześniej projektu badawczego autorów (Kilar, Rachwał, Wiedermann 2008).

\section{ZRÓŻNICOWANIE PRZESTRZENNE POTENCJAŁU PRZEMYSŁOWEGO REGIONÓW UNII EUROPEJSKIEJ}

Zróżnicowanie przestrzenne potencjału przemysłowego w poszczególnych regionach Unii Europejskiej przedstawiono za pomocą miernika syntetycznego obejmującego dwa składowe mierniki empiryczne, tj. liczbę pracujących i wartość dodaną brutto. Wyznaczenie miernika dokonano na podstawie metody Z. Zioło $(1972,1973)$ dla danych za lata 1996 i 2005 w celu uzyskania obrazu współczesnego rozmieszczenia przemysłu oraz tendencji zmian. Analiza potencjału w świetle miernika syntetycznego ma tę zaletę, że wpływ na jego wartość ma zarówno liczba pracujących, mająca istotne znaczenie w przypadku przemysłów pracochłonnych, jak i wartość dodana brutto, która lepiej obrazuje przemysły bardziej zaawansowane technologicznie, o dużych nakładach na prace badawczo-rozwojowe. W sytuacji kiedy przemysł przestaje pełnić swoją wiodącą funkcję w zakresie aktywizacji zasobów pracy, opieranie się tylko na jednym powszechnie stosowanym mierniku zatrudnienia wydaje się niecelowe, gdyż przy takim podejściu uwypuklone byłyby regiony, w których dominuje przemysł pracochłonny, a umniejszono by znaczenie przemysłów bardziej nowoczesnych, o dużej mechanizacji i automatyzacji produkcji, cechujących się wysoką wartości dodaną, który jest charakterystyczny dla najbardziej rozwiniętych regionów UE.

Analiza zróżnicowania przestrzennego obliczonego miernika syntetycznego wskazuje, że do obszarów o wysokim potencjale przemysłu w 1996 r. należały duże regiony cechujące się jednocześnie najwyższym poziomem rozwoju gospodarczego. Należą do nich południowe i zachodnie regiony Niemiec, północne i środkowe regiony Francji, północne regiony Włoch, a także niektóre regiony Wielkiej Brytanii, Portugalia, Katalonia oraz Czechy (ryc. 1). Potencjał ten nawiązuje do ukształtowanej w II poł. XX w. centralnej osi silnego rozwoju społeczno-gospodarczego Europy. Należy przy tym zwrócić uwagę, że potencjał regionów Europy Środkowej-Wschodniej, mimo dosyć wysokiego zatrudnienia w przemyśle, jest stosunkowo niski (wyjątek stanowią tu Czechy). W przypadku Polski największy potencjał skupiają regiony południowy i centralny.

Rozmieszczenie przemysłu w regionach UE w 2005 roku wykazuje niewielkie zmiany względem roku 1996. Obszarem o największej koncentracji działalności przemysłowych są regiony zachodnich i południowych Niemiec, północnych Włoch, środkowej i północnej Francji, Anglii i Beneluksu. Świadczy to o trwałości ukształtowanych struktur przemysłowych, które nawet w okresie szybko zachodzących w ostatnich kilkunastu latach zmian wykazują niewielką skłonność do różnicowania przestrzennego potencjału przemysłowego. 


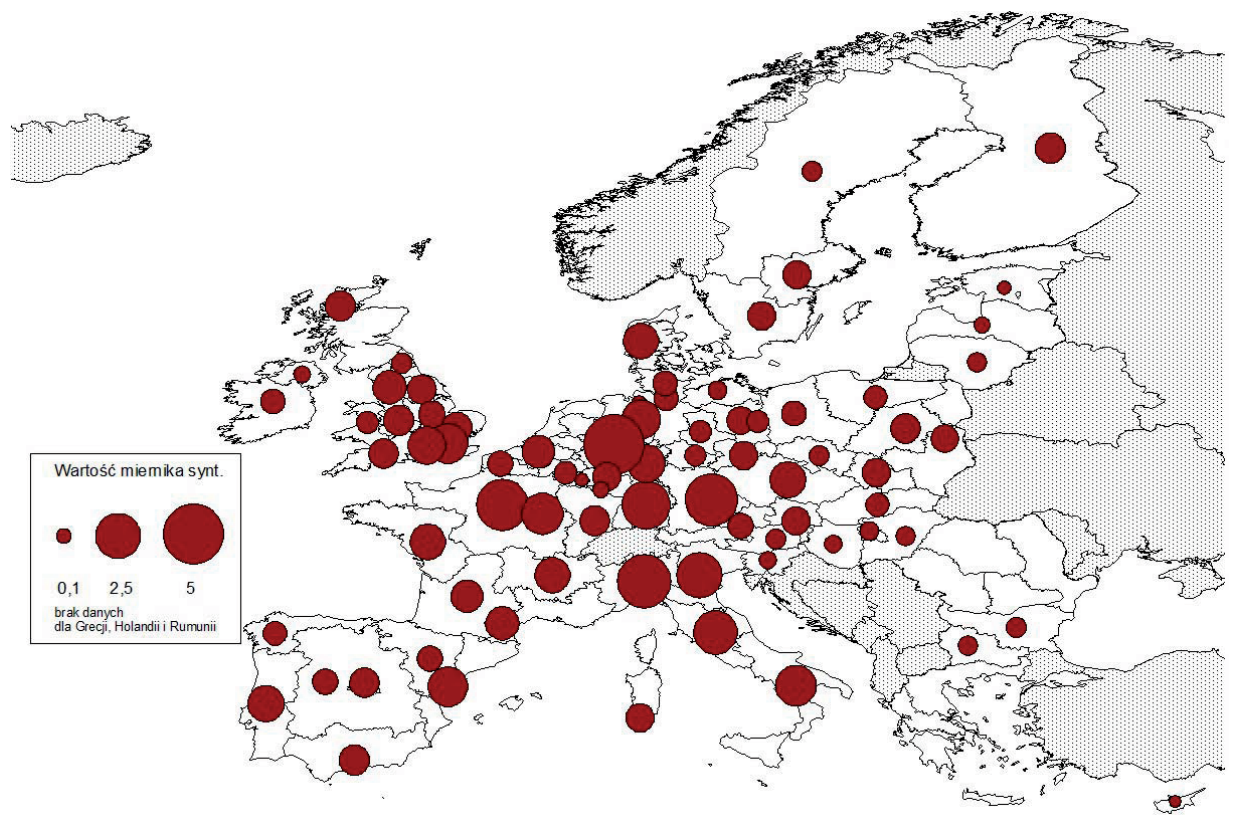

Ryc. 1. Potencjał przemysłowy regionów UE w 1996 r.

Źródło: opracowanie własne na podstawie metody Z. Zioło $(1972,1973)$ na podstawie danych Eurostatu

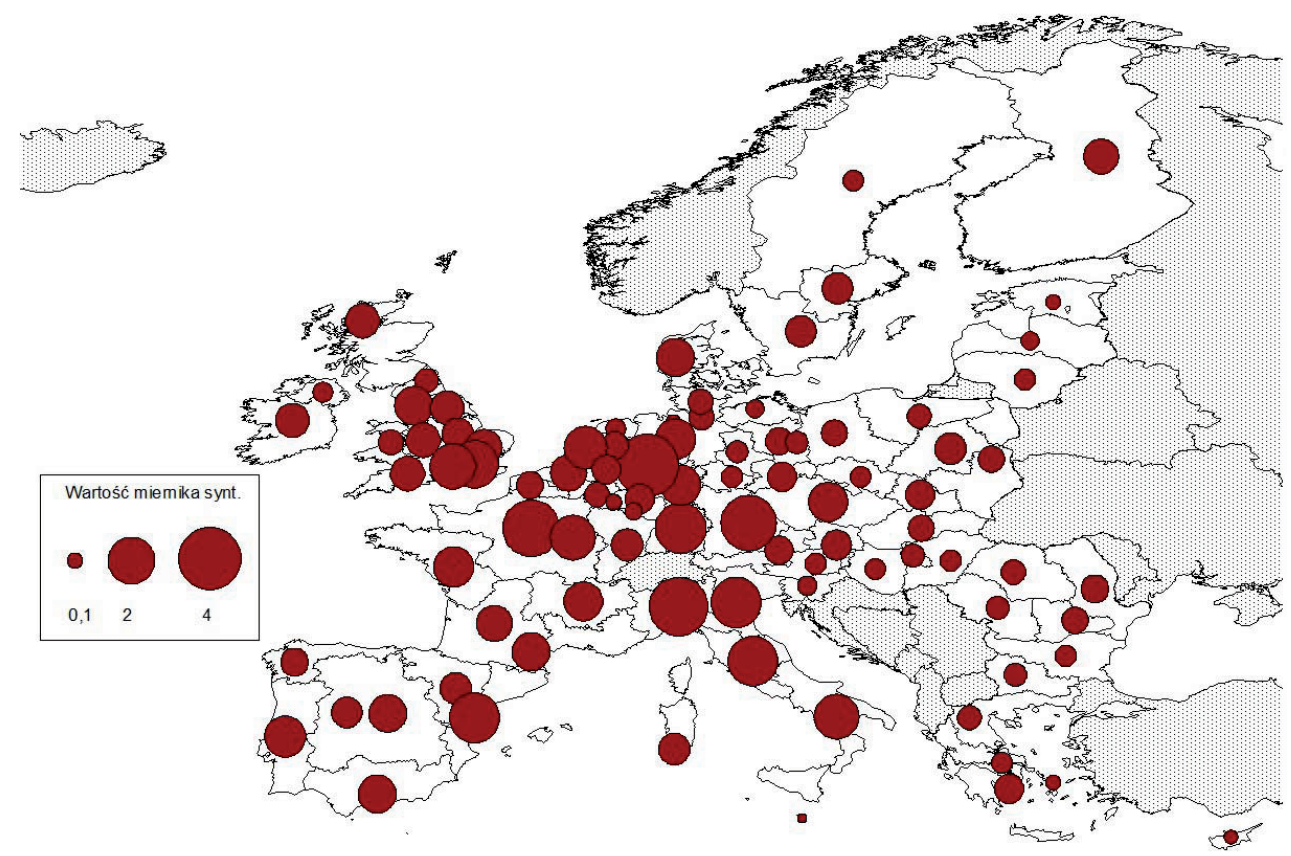

Ryc. 2. Potencjał przemysłowy regionów UE w 2005 r.

Źródło: opracowanie własne na podstawie metody Z. Zioło $(1972,1973)$ na podstawie danych Eurostatu 
W celu uzyskania lepszego obrazu zmian zachodzących w uprzemysłowieniu regionów sporządzono kartogram przedstawiający dynamikę tego zjawiska (ryc. 3). W świetle powyższych kartodiagramów (ryc. 1 i 2) wykazujących niewielkie zmiany, bardziej dokładny obraz ujęcia dynamicznego jest szczególnie istotny z punktu widzenia interpretacji procesów zachodzących w Europie w ciągu ostatnich lat. Z jednej bowiem strony procesy zachodzące w regionach krajów „,nowej” Unii Europejskiej cechują się szybkimi przemianami w zakresie restrukturyzacji przemysłu i dostosowania go do istniejących wymagań gospodarki wolnorynkowej, a z drugiej strony kraje tzw. „starej” Unii cechują procesy relokacji działalności produkcyjnych do krajów o niższych kosztach pracy.

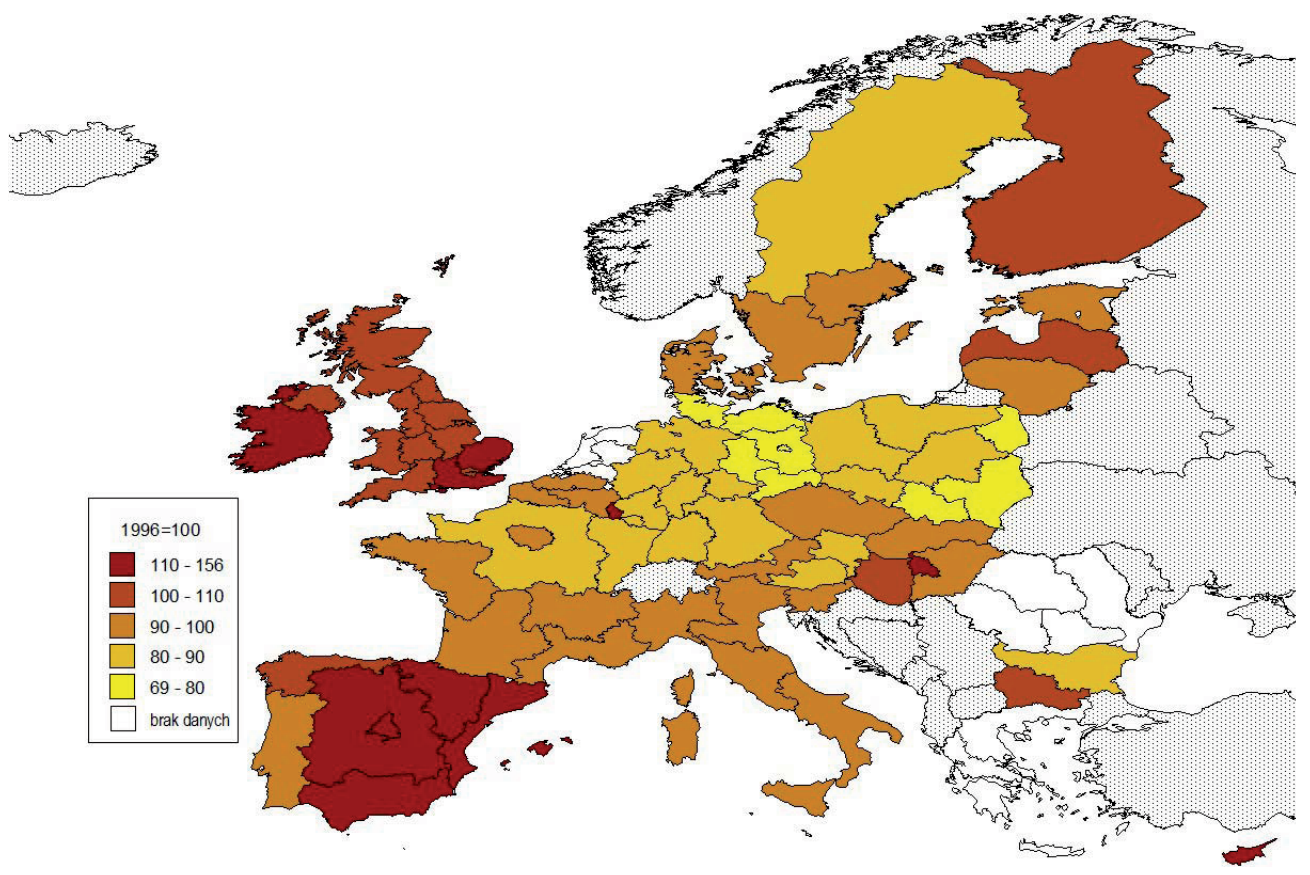

Ryc. 3. Dynamika uprzemysłowienia regionów UE w świetle zmian wartości miernika syntetycznego w latach 1996-2005

Źródło: opracowanie własne na podstawie metody Z. Zioło $(1972,1973)$ na podstawie danych Eurostatu

$\mathrm{Z}$ analizy dynamiki tego zjawiska wynika, że potencjał ten rośnie w wielu regionach Europy, m.in. w Irlandii, Finlandii, Hiszpanii, Portugalii, niektórych regionach Francji Niemiec, Wielkiej Brytanii i Węgier. Większość regionów o długich tradycjach i dużej roli przemysłu oraz regiony dynamicznie rozwijających się krajów, np. Irlandia i Hiszpania, nadal wzmacniają potencjał tego sektora, co nie pozwala na potwierdzenie stawianej w licznych opracowaniach hipotezy o powszechnych procesach dezindustrializacji Europy. Przemiany potencjału przemysłowego są więc raczej wynikiem procesów reindustrializacji, w których przemysł pracochłonny ustępuje miejsca przemysłom wiedzochłonnym cechującym się wyższą wartością dodaną, co niweluje zmniejszającą się rolę przemysłu w bezpośrednim aktywizowaniu zasobów pracy. Jest to wyraźnie zarysowująca się cecha przemysłu tzw. nowej gospodarki (por. Wieloński 2003). 


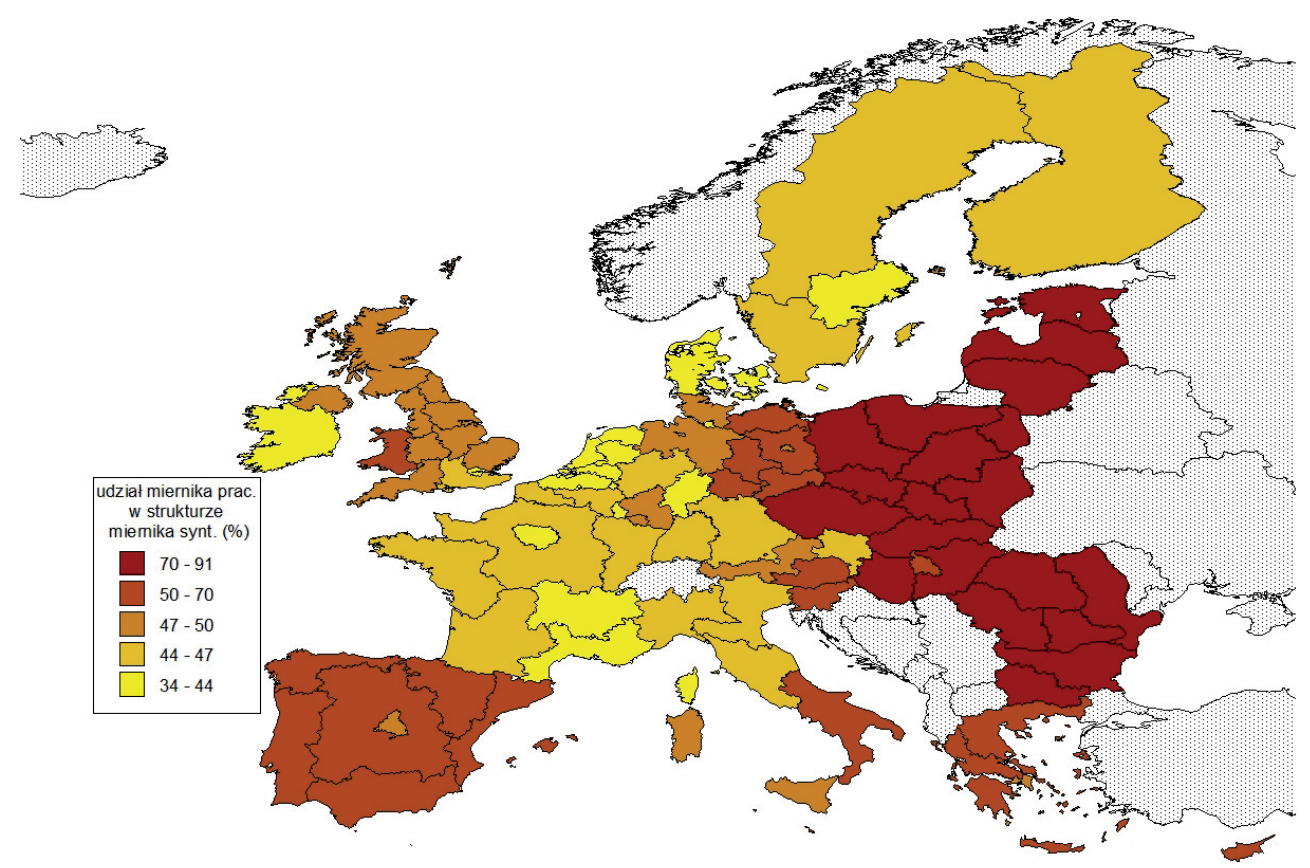

Ryc. 4. Wpływ miernika pracujących na wartość miernika syntetycznego w $2005 \mathrm{r}$.

Źródło: opracowanie własne na podstawie metody Z. Zioło $(1972,1973)$ na podstawie danych Eurostatu

Analiza struktury miernika syntetycznego, którego znaczenie poszczególnych składowych zostało przedstawione na kartogramie (ryc. 4), pozwala określić znaczenie mierników empirycznych oraz stopień ich wpływu na wartość miernika syntetycznego (Zioło 1972, 1973). W przypadku większości analizowanych regionów UE na wielkość potencjału przemysłowego w 2005 r., podobnie jak w 1996 r., największy wpływ miała liczba pracujących. Szczególnie wysoki wpływ tego miernika empirycznego zaznaczał się w regionach Europy Środkowej (w szczególności Bułgarii, Polski, Rumunii, Czech i Słowacji) oraz regionach Hiszpanii, Portugalii, Grecji i wschodnich Niemiec. Duży wpływ wartości dodanej brutto na wartość miernika syntetycznego zanotowano m.in. w Irlandii, niektórych regionach Holandii, Niemiec i Francji. Świadczy to o lokalizowaniu i rozwoju w tych częściach Europy przemysłów nowoczesnych, w szczególności z sektora zaawansowanej technologii, cechujących się właśnie wysoką wartością dodaną.

\section{ZRÓŻNICOWANIE PRZESTRZENNE POTENCJAŁU BADAWCZO-ROZWOJOWEGO (B+R) REGIONÓW UNII EUROPEJSKIEJ}

Cechą charakterystyczną układu przestrzennego zatrudnienia w działalnościach badawczo-rozwojowych Unii Europejskiej (ryc. 5) jest fakt, że regiony o ukształtowanej w przeszłości tradycyjnie dużej roli przemysłu utrzymują pozycje liderów pod względem wielkości potencjału zatrudnienia w sektorze $\mathrm{B}+\mathrm{R}$. Rozwój przemysłu jest bowiem zarówno czyn- 
nikiem jak i wynikiem postępu technologicznego, który wymaga znaczącego udziału prac $\mathrm{B}+\mathrm{R}$, szczególnie w przypadku produkcji o wysokiej wartości dodanej. Prace te związane są nie tylko z rozwojem wyrobów przemysłowych, ale także unowocześnieniem i automatyzacją procesów produkcyjnych.

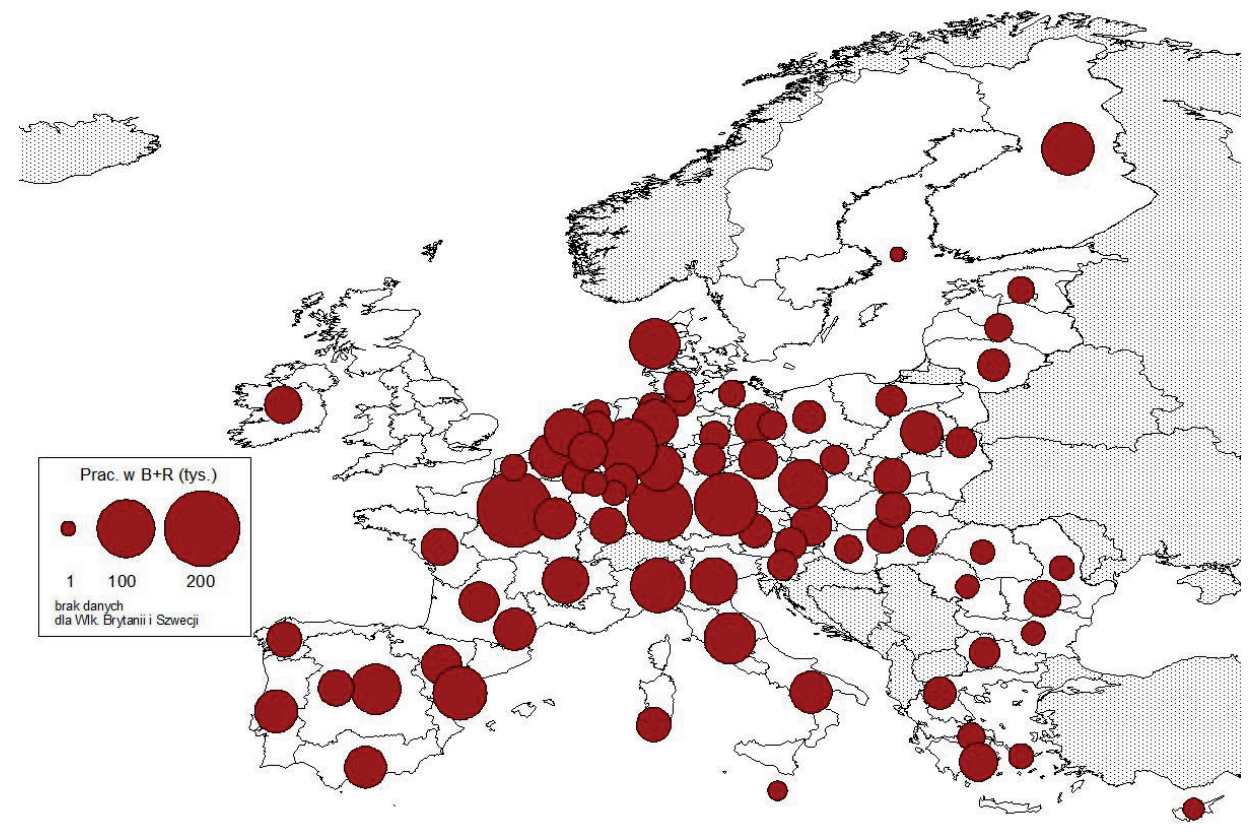

Ryc. 5. Potencjał zatrudnienia w działalnościach B+R w 2005 roku

Źródło: opracowanie własne na podstawie danych Eurostatu

Oprócz regionów wysoko uprzemysłowionych dużą wartością tego miernika cechują się regiony o najlepiej rozwiniętych funkcjach centralnych. W tym przypadku wynika to z lokalizacji licznych i dużych instytucji naukowych oraz naukowo-dydaktycznych w największych miastach Europy.

Zróżnicowanie przestrzenne udziału pracujących w B+R w ogóle pracujących przedstawione na kartogramie (ryc. 6) pozwala zauważyć wyraźnie wyższą wartość tego wskaźnika dla regionów o rozwiniętych funkcjach centralnych (np. Madryt, Berlin), a także tych, w których zlokalizowano wiele zakładów o wysoko zaawansowanych procesach wytwarzania wyrobów, które są charakterystyczne dla przedsiębiorstw przemysłowych funkcjonujących na obszarze południowych Niemiec (m.in. najbardziej innowacyjne koncerny motoryzacyjne), Skandynawii czy Francji. Potwierdzeniem tego zjawiska jest także region Noreste położony w północnej Hiszpanii, którego wysoki udział w zatrudnieniu w działalnościach B+R wynika z lokalizacji wielu nowoczesnych fabryk i towarzyszących im instytucji B+R na terenie znajdującego się tam miasta Saragossa. Niskim odsetkiem pracujących w B+R charakteryzują się natomiast regiony peryferyjne względem głównej osi rozwoju UE, a w przypadku obszarów należących do rdzenia Unii regiony o dużym odsetku pracujących w tradycyjnych branżach przemysłu, jak np. przemysł wydobywczy - zagłębie Saary w Niemczech czy region Groningen w Holandii. 


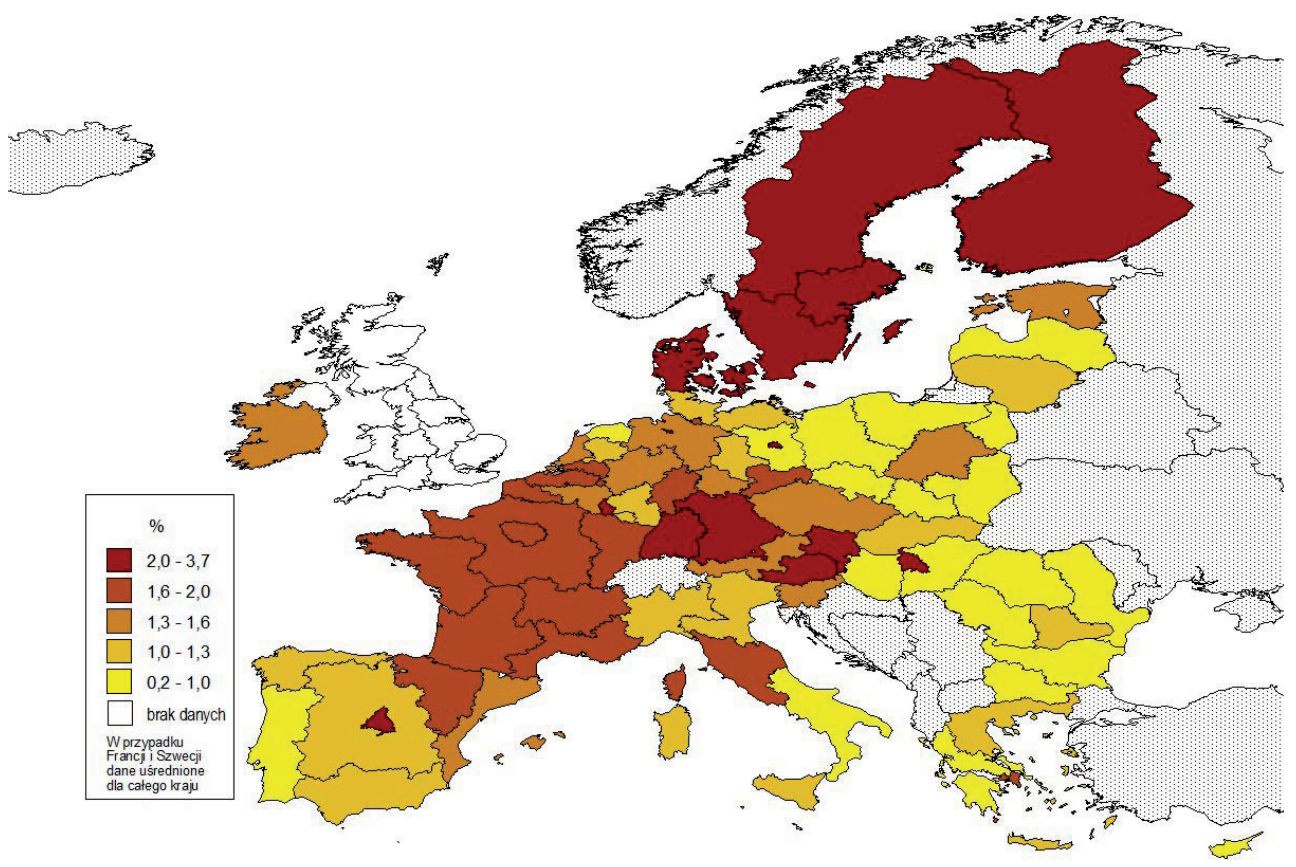

Ryc. 6. Udział zatrudnienia w działalnościach $\mathrm{B}+\mathrm{R}$ w ogóle pracujących w 2005 roku

Źródło: opracowanie własne na podstawie danych Eurostatu

Jeszcze większy kontrast w porównaniu do zatrudnienia w B+R widoczny jest w przypadku nakładów na działalność badawczo-rozwojową na terenie Unii Europejskiej (ryc. 7). Świadczy to większej ilości środków przeznaczanych na badania przez firmy i instytucje zlokalizowane na terenie najbardziej rozwiniętej gospodarczo części UE. Obszar centralny Unii cechuje się największym zagęszczeniem centrów badawczo-rozwojowych oraz central zarządów międzynarodowych koncernów i ich wydatki na badania i rozwój produktów są przypisane tym regionom. Należy zwrócić uwagę także na bardzo wysokie wartości tego wskaźnika dla tych regionów, które to jak w przypadku Ile-de-France czy regionów południowych Niemiec sięgają wartości 15 mld euro, co znacząco przekracza sumy wydatków na tego typu działalność w całych krajach położonych peryferyjnie w UE (za wyjątkiem krajów skandynawskich).

Zróżnicowanie udziału wydatków na działalności B+R w PKB (ryc. 8) pokazuje wyraźną różnicę pomiędzy krajami „starej” i „nowej” UE. Skrajne wartości różnią się od siebie ponaddziesięciokrotnie. Najniższe udziały wydatków występują przede wszystkim na obszarze regionów o niewielkim udziale nowoczesnego przemysłu, któremu towarzyszy bezpośrednie zaplecze jednostek $\mathrm{B}+\mathrm{R}$. Analiza struktury wydatków na badania i rozwój w PKB wskazuje, że największe znaczenie mają w tym przypadku nakłady przedsiębiorstw przemysłowych. Nieliczne dotąd relokacje działów B+R w ramach koncernów międzynarodowych powodują, że w nakładach jeszcze długo będą wykazywać wyraźne różnice w przestrzeni UE. 


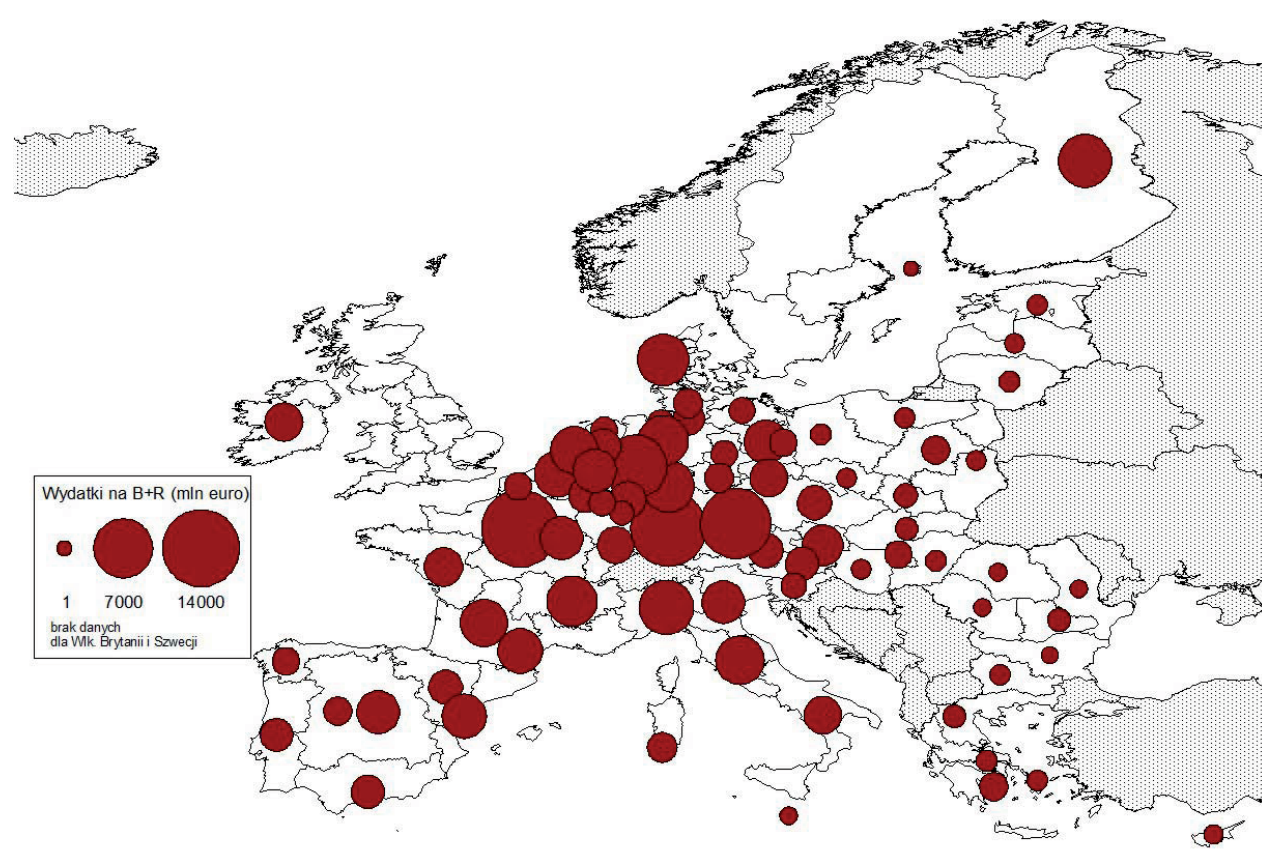

Ryc. 7. Wydatki na działalności $\mathrm{B}+\mathrm{R}$ w 2005 roku

Źródło: opracowanie własne na podstawie danych Eurostatu
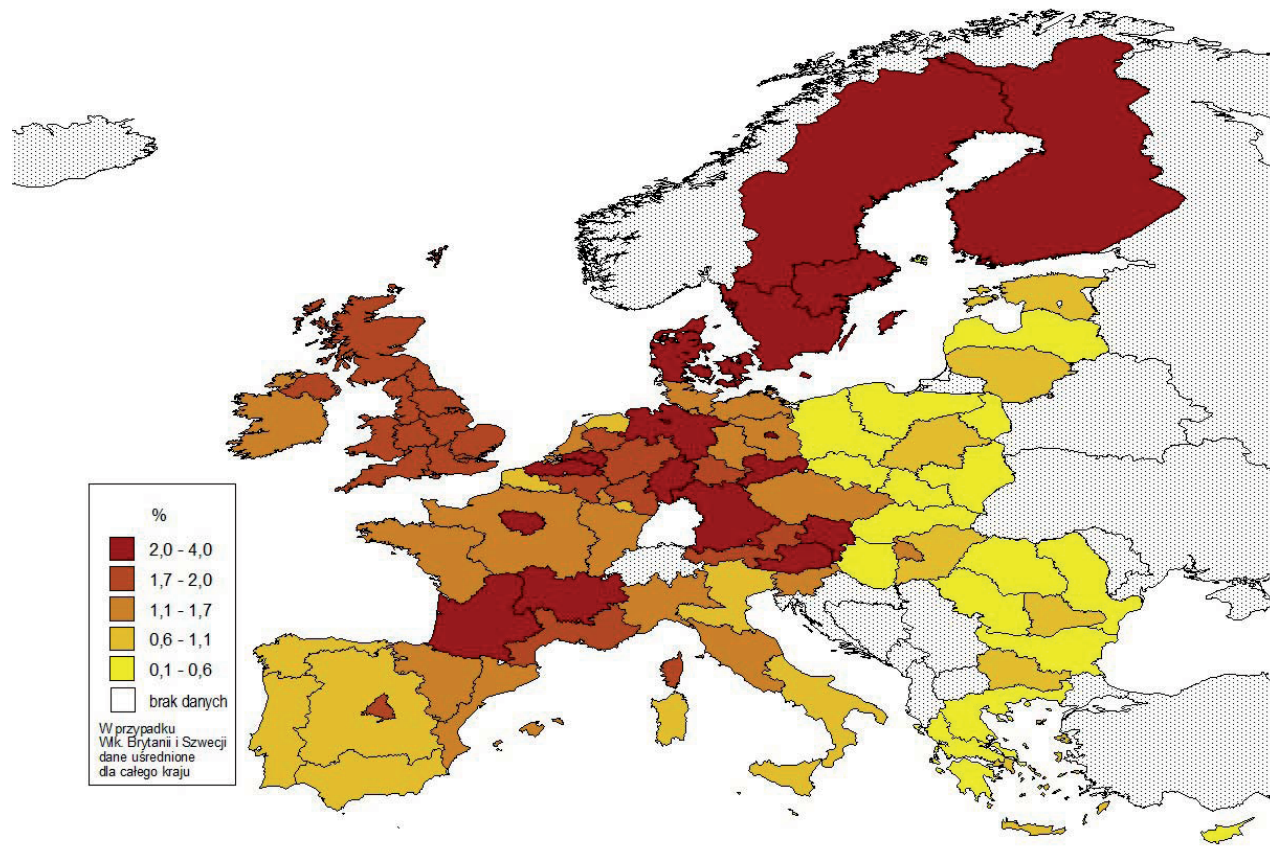

Ryc. 8. Udział wydatków na działalności B+R w PKB w 2005 roku

Źródło: opracowanie własne na podstawie danych Eurostatu 


\section{NAKŁADY NA PRACE BADAWCZO-ROZWOJOWE A WYDAJNOŚĆ PRACY W PRZEMYŚLE REGIONÓW UNII EUROPEJSKIEJ}

Przeprowadzona dla Unii Europejskiej w ujęciu regionalnym analiza relacji wskaźnika nakładów $\mathrm{B}+\mathrm{R}$ na pracującego i wydajności pracy w przemyśle przedstawia wyraźną zależność tych elementów.

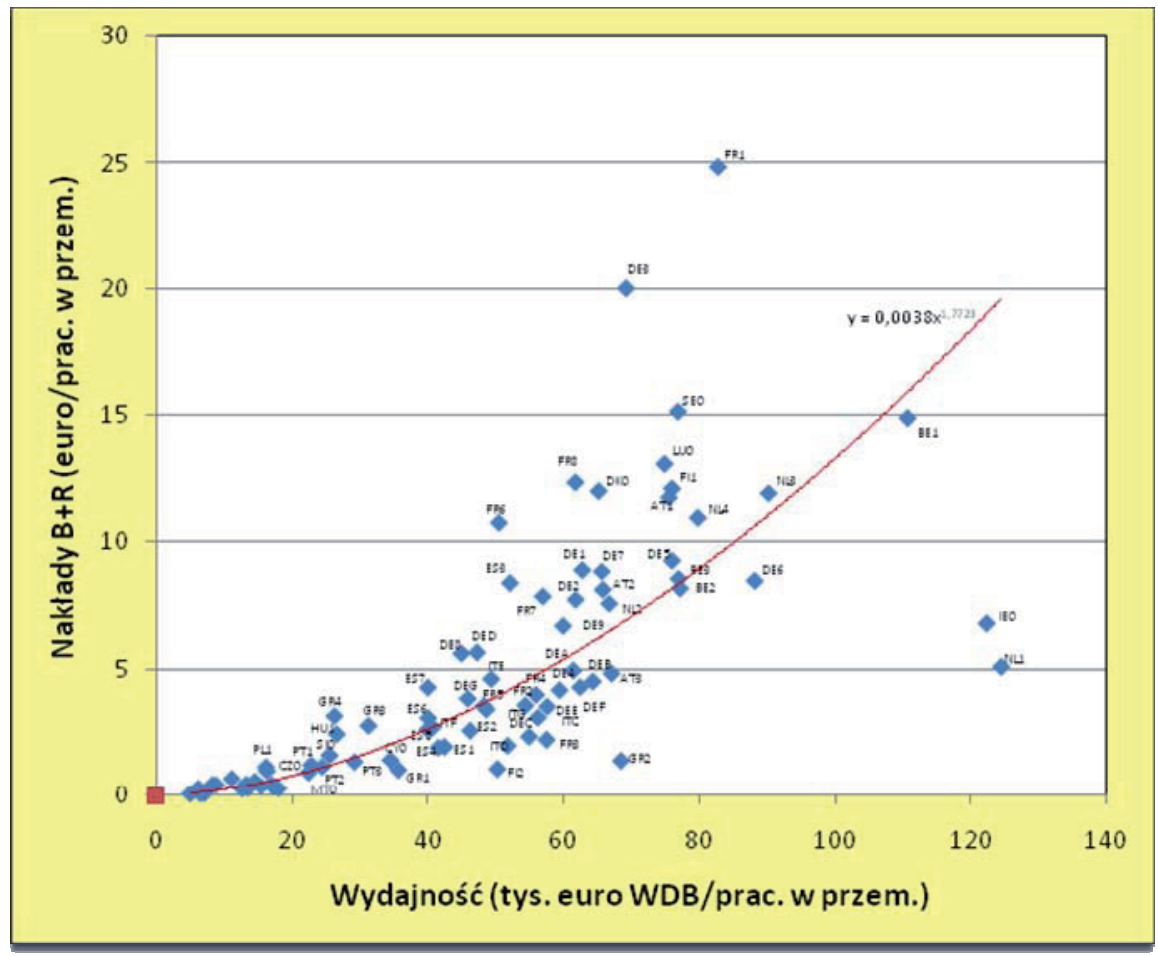

Ryc. 9. Potencjał zatrudnienia w działalnościach $\mathrm{B}+\mathrm{R}$ w 2005 roku

Źródło: opracowanie własne na podstawie danych Eurostatu

Nakłady na działalność badawczo-rozwojową towarzyszą inwestycjom produkcyjnym wytwarzającym innowacyjne produkty bądź technologie o wysokiej wartości dodanej. Nieliczne inwestycje tego typu w krajach Europy Środkowej powodują, iż regiony te cechują się niską wydajnością pracy, wynikającą z produkcji o niższej wartości dodanej oraz niskimi nakładami na działalność B+R. Zmiany w strukturze inwestycji, w tym także lokalizacji centrów badawczych i projektowych, będą prowadziły do zmniejszania dystansu dzielącego „stare” i ,nowe” regiony UE. Jako przykład tych inwestycji można wymienić centrum technologiczne VW w Mlada Boleslav w Czechach, centra badawcze amerykańskich koncernów Delphi w Krakowie czy TRW w Częstochowie. 


\section{WNIOSKI}

Przedstawiony w artykule obraz przestrzennego zróżnicowania potencjału przemysłowego i jego zmian w ostatnich kilkunastu latach oraz analiza zatrudnienia i nakładów na prace badawczo-rozwojowe w poszczególnych regionach Unii Europejskiej pozwala na sformułowanie następujących wniosków diagnostyczno-poznawczych:

- nadal największym potencjałem przemysłowym charakteryzują się regiony należące do centralnej osi silnego rozwoju społeczno-gospodarczego Europy;

- wyraźna jest tendencja do zmniejszania zatrudnienia w przemyśle w większości analizowanych regionów Unii Europejskiej, co oznacza zmniejszanie się znaczenia przemysłu w aktywizacji zasobów pracy;

- zmniejszenie zatrudnienia nie musi jednak oznaczać pomniejszenia roli przemysłu w gospodarce mierzonej innymi miernikami, o czym świadczy w większości europejskich regionów widoczny wzrost wartości dodanej brutto wytwarzanej przez przemysł;

- w niektórych regionach (np. Hiszpanii, Wielkiej Brytanii, Irlandii, Finlandii) obserwuje się wzrost potencjału przemysłowego, co jest przede wszystkim wynikiem dużego wzrostu wartości dodanej brutto wytwarzanej przez przemysł;

- udział przemysłu w gospodarce większości regionów UE ma wyraźną tendencję malejąca, chociaż obserwuje się wzrost tego udziału w słabo uprzemysłowionych regionach;

- istnieje wyraźna zależność pomiędzy wielkością nakładów na działalność B+R i wydajnością pracy mierzoną wartością dodaną brutto przypadającą na pracującego;

- duża część środków przekazywanych na badania i rozwój jest kierowana z obszarów o rozwiniętym przemyśle do regionów centralnych najwyższego rzędu (np. Paryż, Berlin);

- wyraźnie zaznacza się niski w porównaniu z innymi regionami UE udział wydatków na prace B+R w regionach Europy Środkowo-Wschodniej.

W świetle przeprowadzonych rozważań konieczne więc wydaje się podjęcie przez władze krajowe i regionalne działań strategicznych na rzecz zwiększenia finansowania prac badawczo-rozwojowych związanych z wdrażaniem innowacji technologicznych (procesowych) i produktowych w przemyśle. Może się to odbywać, z jednej strony, poprzez większy udział w finansowaniu tych prac przy wykorzystaniu środków z funduszy UE, co pozornie wydaje się niemożliwe ze względu na skomplikowaną sytuację budżetów państwa i jednostek samorządu terytorialnego w warunkach recesji gospodarczej, lecz jest wykonalne ze względu na możliwość wykorzystania środków z funduszy UE. Z drugiej zaś strony może się to odbywać poprzez intensywne działania na rzecz przyciagnięcia inwestycji bardziej wiedzo- niż pracochłonnych i lokalizacji centrów badawczo-rozwojowych międzynarodowych korporacji.

W warunkach kryzysu finansowego i związanych z nim gwałtownych przemian w stosunkach gospodarczych (np. w postaci zerwania dotychczasowych powiązań kooperacyjnych, w tym także w zakresie prac B+R) oraz poszukiwaniem przez firmy oszczędności budżetowych (m.in. poprzez wykorzystanie mechanizmów outsourcingu bądź offshoringu) wyłania się duża szansa na przyciagnnięcie takich centrów do Polski, w której występują wyjątkowo korzystne relacje między jakością naukowo-badawczego kapitału ludzkiego a kosztami jego pozyskania. Działania te w efekcie powinny wpłynąć na zwiększenie udziału kapitału prywatnego w finansowaniu prac B+R i w konsekwencji rozwoju działalności przemysłowych o wyższej wartości dodanej. Powinno to przyspieszyć przemiany przemysłu polskiego w kierunku zwiększenia jego potencjału mierzonego wartością dodaną brutto i podniesienia jego konkurencyjności na rynkach światowych. 


\section{Literatura}

Bossak J., 2001, Międzynarodowa konkurencyjność gospodarki kraju i przedsiębiorstwa. Zagadnienia teoretyczne i metodologiczne, [w:] Bossak J., Bieńkowski W. red., Konkurencyjność gospodarki Polski w dobie integracji z Uniq Europejskq i globalizacji, t. I, SGH, Warszawa, s. 41-53.

Domański B., 1997, Geografia przedsiębiorstw - niedoceniany nurt badań w polskiej geografii ekonomicznej, [w:] Geografia - czlowiek - gospodarka, red. B. Domański, Instytut Geografii i Gospodarki Przestrzennej UJ, Kraków, s. 101-112.

Domański B., Gwosdz K. red., 2005, Dziesięć lat doświadczeń pierwszej polskiej specjalnej strefy ekonomicznej, Mielec 1995-2005, Uniwersytet Jagielloński, Instytut Geografii i Gospodarki Przestrzennej, ARP o. Mielec, Kraków.

Jasiński L.J., 2001, Konkurencyjność gospodarek krajów Unii Europejskiej a ewolucja prowadzonych przez nia polityk, [w:] Bossak J., Bieńkowski W. red., Konkurencyjność gospodarki Polski w dobie integracji z Uniq Europejskq i globalizacji, t. II, SGH, Warszawa, s. 227-236.

Kilar W., Rachwał T., Wiedermann K., 2008, Changes in differentiation of Polish regions' industrial potential within the European Union, [w:] Czapiewski K., Komornicki T. red., New functions of rural and industrial space in central and eastern Europe, Europa XXI, vol. 17, Institute of Geography and Spatial Organization - Polish Academy of Sciences, Academic Division - Polish Geographical Society, Warszawa, s. 145-158.

Misala J., 2001, Istota i mierniki międzynarodowej konkurencyjności gospodarki w świetle teorii wymiany międzynarodowej, [w:] Bossak J., Bieńkowski W. red., Konkurencyjność gospodarki Polski $w$ dobie integracji z Uniq Europejska i globalizacji, t. I, SGH, Warszawa, s. 103-125.

Rachwał T., 2008, Problematyka badawcza funkcjonowania przedsiębiorstw przemystowych, [w:] Problematyka badawcza geografii przemystu, red. Zioło Z., Rachwał T., Prace Komisji Geografii Przemysłu PTG nr 11, Wydawnictwo Naukowe AP, Warszawa-Kraków, s. 53-85.

Rydz E., Szymańska W., 2006, Efekty restrukturyzacji słupskiego ośrodka przemysłowego w okresie wdrażania gospodarki rynkowej, [w:] Efekty restrukturyzacji polskiej przestrzeni przemystowej, red. Zioło Z., Rachwał T., Prace Komisji Geografii Przemysłu PTG nr 9, Wydawnictwo Naukowe AP, Warszawa-Kraków, s. 40-51.

Stryjakiewicz T. red., 2004, Wpływ inwestorów zagranicznych na rozwój regionalny i lokalny na przykładzie GlaxoSmithKline Pharmacenticals S.A. w Poznaniu, Bogucki Wydawnictwo Naukowe, Poznań.

Stryjakiewicz T., 1999, Adaptacja przestrzenna przemyslu $w$ Polsce $w$ warunkach transformacji, Wydawnictwo Naukowe UAM, Poznań.

Szlachta J., 1993, Poland's regional development under economic transformation, Friedrich Ebert Stiftung, Warsaw.

Tobolska A., 2004, Zmiany własnościowe i organizacyjno-ekonomiczne w wybranych dużch przedsiębiorstwach przemysłowych Poznania w okresie transformacji, Bogucki Wydawnictwo Naukowe, Poznań.

Tobolska A., 2006, Nowy model organizacji i funkcjonowania starych przedsiębiorstw przemystowych, [w:] Efekty restrukturyzacji polskiej przestrzeni przemystowej, red. Zioło Z., Rachwał T. Prace Komisji Geografii Przemysłu PTG nr 9, Wydawnictwo Naukowe AP, Warszawa-Kraków, s. $81-97$.

Wiedermann K., 2007, Regionalne efekty mnożnikowe rozwoju przemystu motoryzacyjnego w aktywizacji gospodarczej województwa ślaskiego, [w:] Rola przedsiębiorczości w aktywizacji gospodarczej, red. Zioło Z., Rachwał T., Przedsiębiorczość-Edukacja nr 3, Zakład Przedsiębiorczości i Gospodarki Przestrzennej IG AP, Wydawnictwo Nowa Era, Warszawa-Kraków, s. 24-34.

Wiedermann K., 2008, Koncepcja efektów mnożnikowych w wyznaczaniu wplywu przedsiębiorstw na otoczenie spoleczno-gospodarcze, [w:] Problematyka badawcza geografii przemystu, red. Zioło Z., Rachwał T., Prace Komisji Geografii Przemysłu PTG nr 11, Wydawnictwo Naukowe AP, Warszawa-Kraków, s. 98-106. 
Wieloński, A., 2003, Przemyst Nowej Gospodarki, [w:] Zioło Z., Makieła Z. red., Przemyst w procesie globalizacji, Prace Komisji Geografii Przemysłu PTG nr 6, Wydawnictwo Naukowe AP, Warszawa-Kraków, s. 21-26.

Zioło Z., 1972, Próba konstrukcji miernika syntetycznego w zastosowaniu do badań przemystu, Komisja Nauk Geograficznych, Sprawozdania z posiedzeń Komisji Naukowych PAN Oddział w Krakowie, t. XV/1, Kraków, s. 191-194.

Zioło Z., 1973, Analiza struktury przestrzennej i form koncentracji przemystu województwa rzeszowskiego w świetle wybranych mierników, Folia Geographica, Series: Geographica-Oeconomica, vol. VI, s. 95-116.

Zioło Z., 2001, Współczesne tendencje rozwoju przemystu i ich problematyka badawcza, [w:] Problemy przemian struktur przestrzennych przemystu, red. Zioło Z., Prace Komisji Geografii Przemysłu PTG nr 8, Wydawnictwo Naukowe AP, Warszawa-Kraków, s. 9-20.

Zioło Z., 2008, Procesy transformacji przemystowych układów przestrzennych na tle zmieniajacego się otoczenia, [w:] Procesy transformacji układów przestrzennych przemystu na tle zmieniajacego się otoczenia, red. Zioło Z., Rachwał T., Prace Komisji Geografii Przemysłu PTG nr 10, Wydawnictwo Naukowe AP, Warszawa-Kraków, s. 11-22.

\section{The role of industry in economy of European Union regional systems}

The aim of the paper is to present the role of industrial activity in the economy of European Union regional systems, with a special reference to Poland, measured by the employment rate and gross added value. Defining the range of influence of regional industry should allow us to define the places of accumulation of new development advantages, which is important from the perspective of the development of these areas. To assess the recent changes in the space of European industry in regional systems, a dynamic analysis of the discussed processes was carried out, covering the period of economic transformation of the Central and Eastern Europe countries and their integration with the European Union. To analyze the function of industry in the development of knowledge-based economy, the authors identified the relationship between the amount of investment in industry and the potential employees in research and development activities. The authors also attempt to assess the suitability of various measures of industrial development to determine their role in regional economic systems in the conditions of intensifying processes of globalization and European integration.

\section{dr Tomasz Rachwał}

Uniwersytet Pedagogiczny im. Komisji Edukacji Narodowej w Krakowie

Instytut Geografii

Zakład Przedsiębiorczości i Gospodarki Przestrzennej

e-mail: T.Rachwal@up.krakow.pl

dr Krzysztof Wiedermann

Uniwersytet Pedagogiczny im. Komisji Edukacji Narodowej w Krakowie Instytut Geografii

Zakład Przedsiębiorczości i Gospodarki Przestrzennej

e-mail: kwiederm@up.krakow.pl

mgr Wioletta Kilar

Uniwersytet Pedagogiczny im. Komisji Edukacji Narodowej w Krakowie

Instytut Geografii

Zakład Przedsiębiorczości i Gospodarki Przestrzennej

e-mail: W.Kilar@up.krakow.pl 